\title{
RECENT SUCCESSFUL NESTING OF FERRUGINOUS HAWK IN MANITOBA
}

BRIAN D. RATCLIFF, Box 1551, Stouffville, Ontario, LOH 1 LO and JOHN L. MURRAY, Lyleton, Manitoba. ROM 1GO

On 4 July 1917, Talbot Criddle photographed a Ferruginous Hawk nest with nestlings near the family farm at Aweme, Manitoba (Fig. 1). Little did anyone know that it would be the last Ferruginous Hawk nest photographed in Manitoba until 1984. Hales reported this species nesting along the Assiniboine and Souris rivers in $1927 ;^{2}$ these were the most recently documented nests. This species has never been a common nesting bird in the province, and in Saskatchewan in recent years it has been decreasing. ${ }^{4}$ An historical review of the occurence of this hawk in Manitoba was compiled by Bechard. ' New nest records presented by Bechard were based on sets of eggs in the collections of the Western Foundation of Vertebrate Zoology and the American Museum of Natural History. These egg clutches were collected as follows: one by C.P. Forge, 10 June 1907 near Roseisle; four by J.D. Currie, 10 May 1908 from nests in the extreme southwest; two by D. Ogg, 20 May 1923 and 2 May 1924 from nests near Pierson. A survey of birds in southwestern Manitoba from 1974-78 by Knapton failed to find any active Ferruginous nests. ${ }^{5}$ It was assumed by Bechard that the species was no longer breeding in the province. ${ }^{1}$

On 2 July, the junior author and his wife Joan noticed two large buteos divebombing two coyotes in a pasture $10 \mathrm{~km}$ west of Lyleton. With a spotting scope thay identified the birds as Ferruginous Hawks. A scan of the pasture revealed a nest with young in a lone Trembling Aspen tree. While they were watching the nest, one adult Ferruginous Hawk came into view and landed at the nest. A return visit on 4 July disclosed that

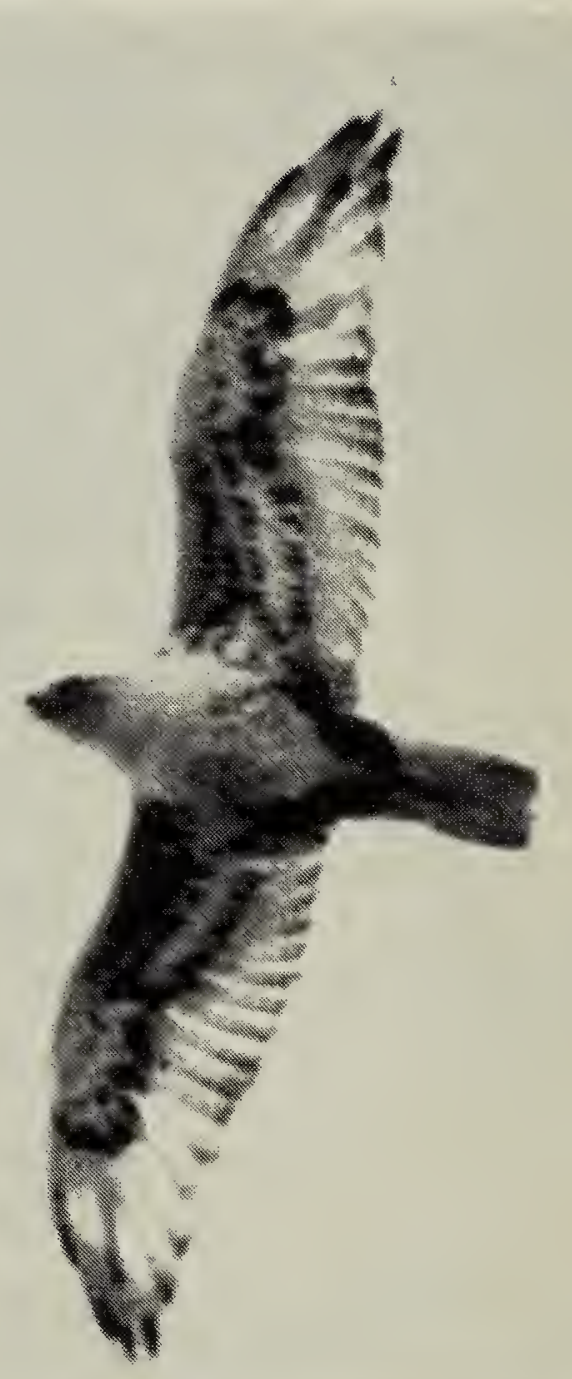

Ferruginous Hawk Brian D. Ratcliff

there were two young at the nest. Between 8 July and 17 July, verification of the occupancy of the nest by Ferruginous Hawks was made by Dennis Fast, Jerry Greenly, William J. Walley, Ralph J. Wang and ourselves. During this period the nest was photographed several times. On 17 July, Walley found and photographed three well-feathered young in the nest. Where this additional bird came from is not clear, but it could have fledged early and been on the ground during earlier visits. All three young had fledged by 19 July. An addled egg $(60.65 \mathrm{~mm} \times 48.05 \mathrm{~mm})$ collected from the nest 23 July was delivered to Herb 


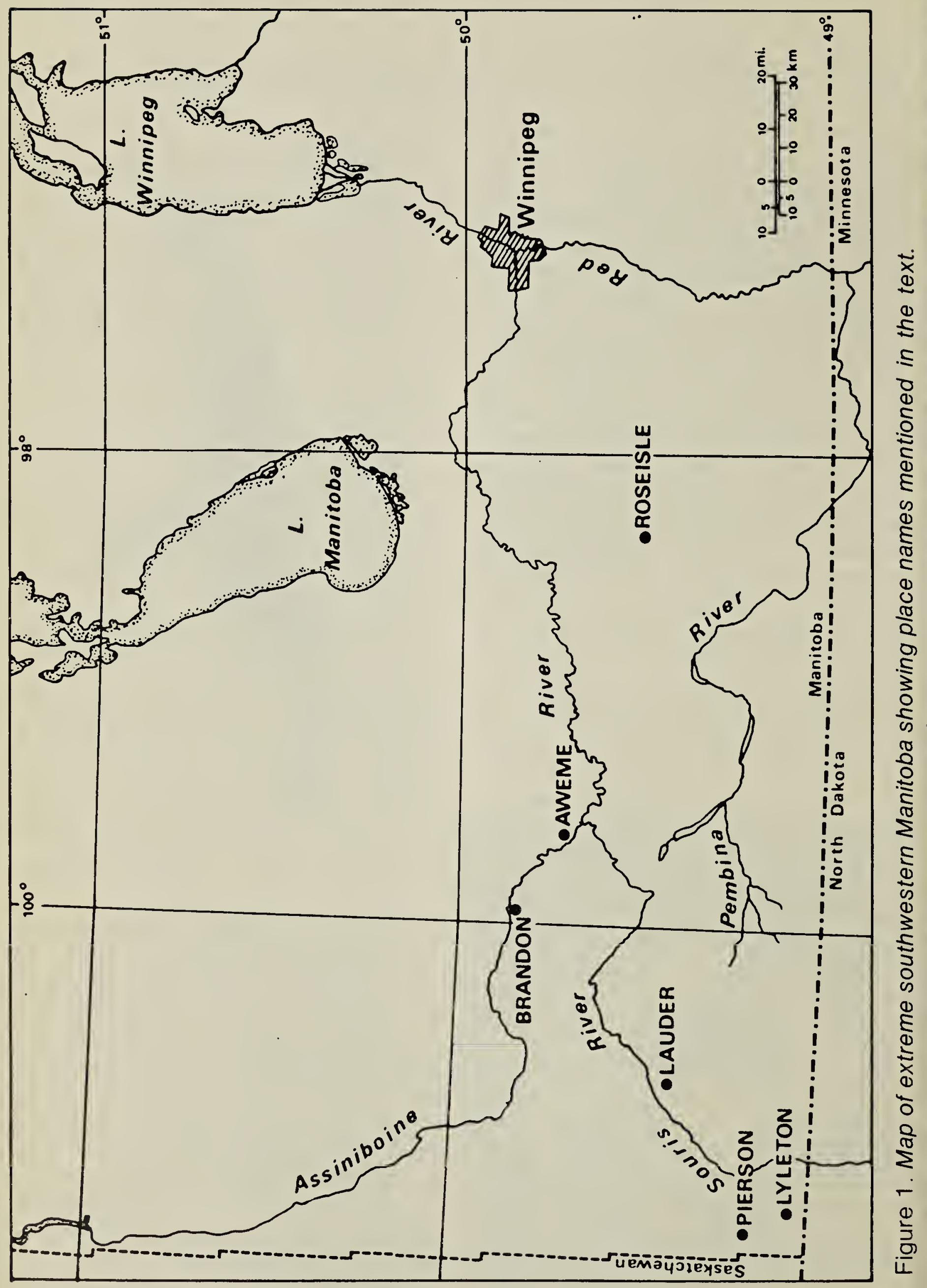




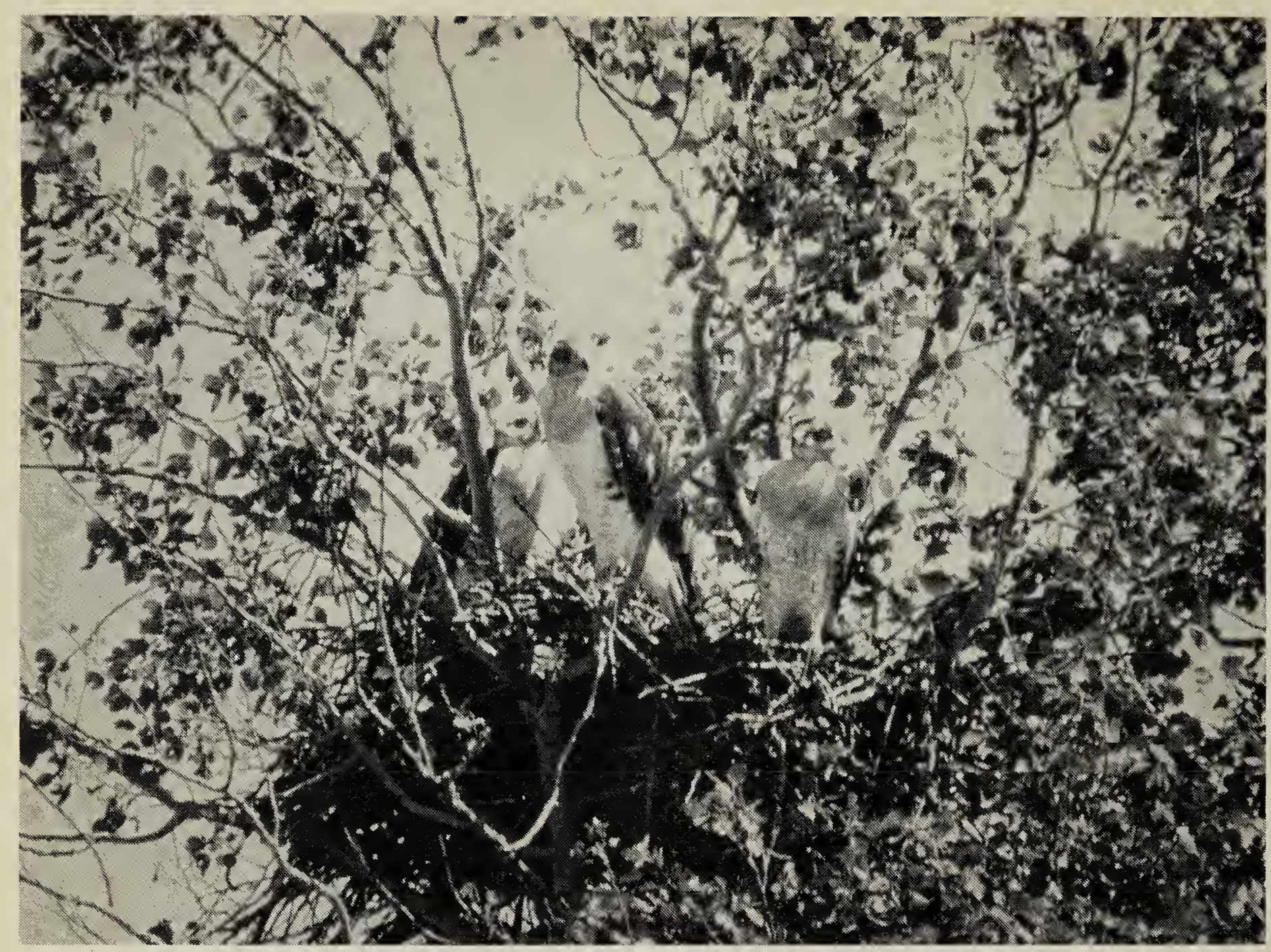

Young Ferruginous Hawks

William J. Walley

considered by the Department of Natural Resources.

We feel that the species has been overlooked in the past and quite probably has been nesting here in limited numbers. Since this hawk became designated as a threatened species by the Committee on the Status of Endangered Wildlife in Canada (COSEWIC), more people are starting to look closely at all raptors in attempts to sight Ferruginous Hawks. It is this interest by local birders that led to the discovery of the first recorded Manitoba nesting of the Ferruginous Hawk in 57 years.

We wish to thank the World Wildlife Fund (Canada) and the Manitoba Department of Natural Resources Wildlife Branch for their support of the Manitoba Burrowing Owl Survey. These Ferruginous Hawk sightings were made while conducting this survey. Horst Schell kindly prepared the figure. Thanks also to Robert W. Nero for his constructive review of this report.

'BECHARD, M.J. 1981. Historical nest records for the Ferruginous Hawk in Manitoba. Canadian Field-Naturalist 95:467-469.

${ }^{2}$ HALES, B.J. 1927. Prairie birds. MacMillan, Toronto.

${ }^{3}$ HOUSTON, O.S. 1982. Artificial nesting platforms for Ferruginous Hawks. Blue Jay 40:208-213.

${ }^{4}$ HOUSTON, C.S. and M.J. BECHARD. 1984. Decline of the Ferruginous Hawk in Saskatchewan. American Birds 38:166-170.

${ }^{5}$ KNAPTON, R.W. 1979. Birds of the Gainsborough-Lyleton region. Saskatchewan Natural History Society, Special Publication No. 10 Regina.

6 SCHMUTZ, J.K. 1983. Artificial nests for Ferruginous Hawks in southeastern Alberta. Special report for the Alberta Fish and Wildlife Division. 